\title{
Teaching Research on Vocational English Based on Learning Needs
}

\author{
Huafang Cui \\ College of Tourism Foreign Languages, Jiangsu Institute of Commerce, Nanjing, 211168, China \\ hunter2011@foxmail.com
}

Keywords: Learning need, Vocational education, College English, Classroom teaching

\begin{abstract}
Nowadays, English for vocational college students, is not only a compulsory course but also a subject that plays an important role in their comprehensive competence development and future career path. However, because of the impact rooted in Chinese traditional education, there are now a great number of problems existing in the vocational English education, which produces negative effects on the enhancement of teaching results. This paper is going to give a comprehensive analysis of current conditions about vocational English teaching, on the basis of learning demand, as well as the corresponding solution measures. Hopefully, it could, to some extent, support the development of teaching activities on vocational English class.
\end{abstract}

\section{Introduction}

Under the influence of college English tests, students usually attach great importance to the English study during their vocational education periods. However, at the same time, since college English tests focus more on students' mastery in theoretical knowledge than in their communicative competence, it to a certain degree, results in some negative effects on students' enhancement of English comprehensive competence during their study, which does harm to students' all-round development. According to relevant surveys and researches, most vocational English classes in China are deficient in the cultivation of students' capability in listening, speaking and communicating. What's worse, the excess of attention they paid to the English grammar and written tests leads to an unexpected consequence that students become uninterested in English study, and consequently, here comes the unsatisfactory teaching result. Therefore, in this new age, it is necessary to make a reform in teaching aimed at students' learning needs, in order to improve their English competence and to lay the foundation of their future development, and it will make the English education meet students' needs of English learning as well as an excellent study environment, thus, the teaching results will be greatly enhanced in the end.

\section{The Theory of Demand Analysis}

From the aspects of natures and forms, demand can usually be divided into two categories, the society and individuals. For social demand, it mainly contains two types, the subjective demand and the objective one: subjective demand basically refers to the employers' present need for technical college graduates in terms of their comprehensive English, thus, it is quite ideal to some degree; however, the objective demand stands for the need of a specific job position for graduates' English competence, which means such a demand is born with social reality, and that's what makes it objective. On the other hand, individual demand reflects actual reactions of graduated students facing with various needs in society. The analysis of demand is essentially, a kind of research theory as well as a scientific research method, which aims to study and analyze a specific topic by doing self-inspection, observation, communication, survey and research, and those achievements will be finally applied into teaching study of specialized English ${ }^{[1]}$. Hutchinson and Waters, two key investigators in the analysis of demand theory, point out that no matter for specialized English education or general English teaching, every kind of classroom teaching has to be connected with their students' need in reality, that is to say, the analysis of demand is a significant teaching activity concentrated on domestic situation and educational practicability. 
The demand analysis mainly contains two key parts, the analysis of target demand and of learning need. The analysis of target demand, in details, means students' analysis of their study-task completion after class, including learning directions, study goals and their actual mastery in English, whereas the analysis of learning demand is made for teachers to gain deeper understanding about students' advantages in language and their learning attitude and expectation towards English before they deliver any lecture. In other words, the demand analysis represents a combination of two scientific analysis models, the analysis of target demand as well as the one of learning demand.

\section{The Present Learning Demand for English Study from Vocational Students}

The Demand for Options in Teaching and Teaching Contents. According to relevant surveys and researches, currently, the English education in vocational colleges mainly depends on self-directed study and graded teaching both with textbooks of high similarity. Students in vocational colleges are greatly dissatisfied with English education at present, of which half of them complain that teaching materials cannot meet their learning needs, and students expect a further acquisition of deeper knowledge so that they can improve their comprehensive competence in English and put the knowledge into practical use ${ }^{[2]}$. However, in reality, to complete the study task, teachers usually pay much attention to the textbook itself rather than the introduction of extra-curriculum knowledge, thus, such ignorance to a certain degree, leads to the high similarity between textbooks and in-class instructions, which negatively influences students' enthusiasm in English and the corresponding teaching results. Overall, it is difficult for Chinese vocational colleges to evoke students' interest in English study merely by their English teaching contents, which is extremely bad for the improvement of their comprehensive competence in English. Under such an educational model, students have to explore the course by themselves out their own learning demand, which reflects vocational college students' learning desire in self-directed study, and that will play a positive role in the teaching reform and students' all-round development.

The Demand in the Aspect of Class Teaching. The survey shows certain gap exists between English classroom teaching form of vocational colleges and students' actual demand. English teachers of vocational colleges generally choose to sacrifice the teaching mode which can motivate students' enthusiasm, but take dull teaching courseware explanation and analysis as the main teaching mode in order to complete teaching tasks. Thus, students' dominant role is affected and they cannot really participate in classroom teaching. Certainly, adverse effects are generated on their learning effect. Under such teaching mode, students are in the passive position in English teaching and they are forced to accept rigid and obsolete teaching mode, which may easily trigger their feeling of study weariness. In essence, an overwhelming majority of students in vocational colleges hope teachers teach in English partly, and create teaching situation and corresponding English communication environment so as to boost students' English communication level ${ }^{[3]}$. However in actual English classroom teaching, some students urgently hope teaches can alter teaching mode and create favorable language learning environment. Some college students consider even if teachers create teaching situations in classroom teaching process and organize students to conduct situational dialogues, students improve communication ability just a little in the whole learning process. These situations directly show students' initiative for classroom learning is relatively low and also indicate that English teaching reform implemented by vocational colleges fails to change teaching defects in essence and becomes formalistic. Thus, students' learning initiative cannot be effectively mobilized, and classroom teaching design cannot meet students' learning needs and fails to play a positive role in improving and enhancing teaching effect.

Demand in the Aspect of Expectation for teachers' role. It is seen from the analysis based on the perspective of students' learning needs that, compared with knowledge-transference teachers in vocational colleges, students expect that teachers can become the assistants and guides in teaching activity. Students hope teachers guide, help and encourage them in teaching process. Meanwhile, they also expect teachers can set strict learning plan or teaching evaluation. It thus can be seen that teachers' role in teaching is contradictory to some extent. The survey indicates ideal vocational 
English teachers should be able to apply various teaching methods flexibly, own a wide range of knowledge and strong sense of responsibility, love their work, treat students sincerely and guide students to keep on improving self-study effect. Furthermore, more than half students hope teachers pay close attention to their study and growth, and give corresponding encouragement and criticism according to their learning effect ${ }^{[4]}$. In one word, students in vocational colleges generally have high requirements for teachers' comprehensive English quality and hope teachers motivate their English learning enthusiasm in teaching practice and cultivate their English learning interest. In this way, students can communicate and exchange with teachers well in learning process, improve comprehensive English quality and lay a foundation for future social development.

\section{English Teaching Reform Based on English Learning Needs}

In the face of new social situation and era development in the new period, English teaching of vocational colleges must make an active response to national requirement to carry out corresponding reform, carry out teaching activities with certain purpose in a planned way through analyzing students' English learning needs, practically improve vocational English teaching effect, create favorable environment for improving students' comprehensive English accomplishment and facilitate students' all-round development. Next, this paper analyzes this problem in detail.

To Perfect English Textbooks and Enrich Teaching Contents. It can be seen from the above analysis that, China's vocational colleges lack attention to professional English teaching in teaching practice; English textbooks lack scientificity and pertinence and pay much attention to the research on theoretical knowledge. Such teaching cannot adapt students' English learning needs now. Especially as information technology develops and it is widely applied in educational field, traditional English textbooks start to fuse with information technology, and three-dimensional textbook design mode appears. But since three-dimensional textbooks of English specialty have certain defects in development and application process, relevant teaching resources cannot be fully applied. Besides, English course and textbook cannot be organically combined in teaching process, which imposes adverse effects on teaching effect. At the same time, some vocational colleges construct corresponding network platform for English teaching. Although the platform can offer certain convenience for students to acquire English learning materials, network information exchange platform cannot be effectively utilized, because students' learning autonomy is poor. Meanwhile, the limitation of traditional English textbooks cannot be compensated. Thus, in order to meet students' learning needs and boost students' comprehensive English quality through classroom practice, vocational colleges should attach importance to selecting contents of English textbooks which should own basic features and functions of language teaching and motivate students' autonomous learning interest and intensify their responsibility awareness ${ }^{[5]}$. On this basis, vocational colleges may start from the following aspects to improve English textbooks. Firstly, the selection of teaching contents should be student-oriented. It is required to fully analyze students' intelligence factor, non-intelligence factor and learning content generated in current social environment so as to satisfy students' learning needs to the largest extent. Secondly, the design of textbook content difficulty should be based on students' independent completion or completion through teamwork, and the textbook should guide students step by step. Thirdly, personalized English personalized system may be designed in the textbook so that students can know their learning situation according to self-testing system in the learning process and then enhance their learning initiative. Finally, English communication situations maybe designed to guide students to carry out practical operation and create conditions for enhancing and improving students' English ability.

To Optimize Course Design and Enhance Students' Autonomous Learning Ability. English courses in vocational colleges are generally composed of special English knowledge and basic English knowledge. The coordination and coexistence of the two exert a great influence on the promotion of teaching effect. Similarly, the deficiency of either part will result in the failure to reach expected teaching effect and to meet students' English learning needs. Thus, vocational colleges should pay attention to course design, take into account of humanity and instrument property of English teaching, deem comprehensive English quality cultivation as the teaching emphasis and 
boost teaching effect. Furthermore, since vocational colleges in different regions are influenced by local talent demand, there is certain difference in talent training objective setting. Naturally, English course setting is emphasis. Vocational colleges must avoid blindly reference to successful experiences of other colleges, but should specify English learning need through survey, rationally design courses according to the needs and enhance students' autonomy. Simply speaking, English course design of vocational colleges should stick to student-centered idea, furthest satisfy students' English learning needs, give students the right of autonomous learning and exploration and improve teaching effect.

To Boost Teachers' Professional Quality and Innovate for Teaching Mode. In current stage, English teachers of vocational colleges generally boast high English level, but their teaching ability is limited and can neither infuse English knowledge to students in an all-round way nor cultivate students' comprehensive English skills. Thus, they cannot meet students' learning needs, and the teaching effect is not satisfying. Based on this, vocational colleges should organize teachers to participate in training regularly, keep on improving their teaching level, create teaching methods, carry out teaching activities based on students' learning needs and motivate their learning enthusiasm so that students can obtain better learning effect in the limited time. For instance, when teaching relevant knowledge about festival, teachers may start from students' interest in foreign festivals and add national customs of relevant foreign festivals in class so as to broaden students' vision and further boost their learning initiative.

\section{Conclusion}

In conclusion, vocational English teaching should start from students' learning needs and implement teaching reform based on market demand for talents in the new period. Meanwhile, vocational colleges should regard students as the center, enrich textbook contents, innovate for classroom teaching mode, promote teaching effect and lay a foundation for students' future development.

\section{References}

[1] G. Chen, Study on Vocational English Teaching Strategy Based on Demand Perspective. Journal of Taiyuan Urban Vocational College, 2014(6):115-116.

[2] Y.W. Xu, Survey of Vocational English Teaching Based on Learning Needs - Sampling from Nursing, Pharmacy and Logistics Management Specialties of Xiangtan Vocational College. Xiangtan Vocational College, 2012.

[3] X.Y. Zhao, Vocational English Teaching: How do students' learning needs guide improvement of vocational English teaching effect. Educational Circle, 2011(24):122-123.

[4]S hao Yingchun, Vocational English Teaching Based on Perspective of Students' English Learning Needs. Academy, 2014(13):90-91.

[5] P.F. Yu. Enlightenment of English Learning Needs of Vocational College Students on Selection of Vocational English Teaching Content. Communication of Vocational Education, 2011(18):26-27. 